\title{
Long-Term Return Reversal: Evidence from International Market Indices
}

\author{
Mirela Malin ${ }^{\mathrm{a}, \dagger}$ and Graham Bornholt ${ }^{\mathrm{b},{ }^{*}}$ \\ ${ }^{a}$ Department of Accounting, Finance and Economics, Griffith Business School, Griffith \\ University, Gold Coast, Queensland, 4222, Australia \\ ${ }^{\mathrm{b}}$ Department of Accounting, Finance and Economics, Griffith Business School, Griffith \\ University, Gold Coast, Queensland, 4222, Australia
}

This paper documents evidence of reversals in the long-term returns of international equity markets. We use recent short-term performance to better select contrarian securities that appear ready to reverse. Our late-stage contrarian strategy consistently provides stronger evidence of long-term return reversal than does the traditional pure contrarian strategy when applied to developed and emerging market indices. Despite an absence of cross-sectional contrarian profits for developed markets in our post-1989 subsample, longitudinal analysis provides strong evidence of reversals during this period. Overall, our results suggest that the reversal of long-term returns may be stronger and more pervasive than is generally understood.

Keywords: Contrarian effect; International financial integration; Developed markets; Emerging markets

EFM Classification: $310,350,630$

*Presenting author. Telephone +61 (0)7 5552 8851, fax +61(0)7 5552 8068, e-mail g.bornholt@griffith.edu.au. †Telephone +61 (0)7 5552 7719, fax +61(0)7 5552 8068, e-mail m.malin@griffith.edu.au . 


\section{Introduction}

Following the landmark paper by DeBondt and Thaler (1985), traditional pure contrarian strategies buy portfolios composed of securities with low long-term past returns (losers) and sell portfolios made up of securities with high long-term past returns (winners). DeBondt and Thaler $(1985,1987)$ show that for portfolios of US stocks formed on the returns of the past three to five years, losers have high future returns whereas winners have low future returns. While DeBondt and Thaler find that their results are consistent with investor overreaction, Fama and French (1996) report that this pattern of long-term return reversal in US stocks can be explained by the Fama-French three-factor model. ${ }^{1}$

A difficulty with using traditional contrarian strategies to uncover long-term return reversal effects in security returns is that not all long-term losers and winners are equally ready to reverse their performances. The key insight is to utilize recent short-term performances to help identify which securities are more ready to reverse their long-term performances. For example, long-term losers whose recent short-term performances are also poor seem more likely to continue to do poorly in the immediate future rather than reverse. Such losers indicate no readiness to reverse even if they do eventually reverse. On the other hand, long-term losers with relatively good recent short-term performance seem better candidates for the reversal of their long-term performance. A similar story applies to long-term winners. Long-term winners with relatively good recent short-term performances appear less likely to reverse soon when compared with long-term winners with relatively poor recent short-term performances.

Given these considerations, we propose a new contrarian strategy, called the latestage strategy. The late-stage contrarian strategy buys long-term losers with relatively good recent short-term performances and shorts long-term winners with relatively poor recent short-term performances. Our expectation is that the late-stage strategy will be more

\footnotetext{
${ }^{1}$ Other studies investigating the contrarian effect include those of Chopra, Lakonishok, and Ritter (1992), Richards (1997), and Balvers, Wu, and Gilliand (2000).
} 
profitable than the traditional pure contrarian strategy and should lead to an improved capacity to detect any underlying long-term return reversal effects.

This paper compares the late-stage strategy with the traditional contrarian strategy and contributes to the literature as follows. First, it examines the late-stage and pure contrarian strategies using a sample of 18 developed market equity indices and 26 emerging market indices. ${ }^{2}$ We find that the late-stage strategy is consistently the most profitable strategy and that it provides significant evidence of reversal in long-term returns for both the developed and emerging markets cases.

Second, the post-1989 subsample of developed markets tells a different story. Neither of the two cross-sectional strategies detect any evidence of long-term return reversal in the developed market indices during this period. One possible explanation for this lack of evidence is that increased correlation between developed markets in recent years may have led to reversals being synchronized to such an extent that they could not be detected by cross-sectional methods. This possibility is examined using a longitudinal approach. The approach uncovers strong evidence of a common reversal in the long-term returns of developed markets post-1989.

The remainder of the paper is organized as follows. Section 2 describes the sample and the methodology employed to construct and test the various contrarian strategies. Section 3 presents the main empirical results. Section 4 conducts a longitudinal study to investigate why developed markets' cross-sectional strategies have been unprofitable post1989. Section 5 presents some closing comments.

\section{Data and methodology}

Monthly total returns data are obtained from Datastream for 44 Morgan Stanley Capital International $(\mathrm{MSCl})$ market indices. Returns are calculated from prices with reinvested gross dividends (i.e., excluding withholding taxes) converted to US dollar terms.

\footnotetext{
${ }^{2}$ Previous predictability studies using these indices include those of Richards (1997), Balvers et al. (2000), Shen, Szakmary, and Sharma (2005), and Balvers and Wu (2006).
} 
Returns are measured in US dollars to facilitate the interpretation of results across markets and because the various strategy profits reflect the results that would be available to a US dollar-based investor. This approach is consistent with related studies, such as that of Balvers and Wu (2006). The time frame for the study extends from January 1970 to January 2011, with the number of observations for each country ranging from 193 to 493.

Table 1 presents summary statistics for the sample showing the monthly mean return and standard deviation for each index. To better understand the performance of indices in different global settings, the countries in Table 1 are classified into two groups: Developed markets are presented in Panel A, while emerging markets are listed in Panel $\mathrm{B}$. The developed markets analysis performed in this study is conducted on the same set of 18 developed market indices as in that of Balvers and Wu (2006), while the emerging markets sample is based on MSCl's own classification and comprises 26 indices. While the developed markets indices' returns are available from January 1970, the first emerging market indices' returns start from January 1988.

This paper compares and contrasts the late-stage contrarian strategy with the corresponding pure contrarian strategy for both developed and emerging market indices. The formation methodology for these competing strategies is presented in the next sections. In all cases, portfolios are formed for the developed and emerging markets separately, using the same procedure for each.

\section{[Table 1 about here]}

\subsection{Pure contrarian strategy}

At the beginning of each month, the indices are ranked based on their past $\mathrm{J}$-month returns $(J=36,48$, or 60 months). Each month $t$, the strategy buys the long-term loser (LL) portfolio consisting of the $25 \%$ of indices that have the lowest past $J$-month returns and sells the long-term winner (LW) portfolio comprised of the $25 \%$ of indices that have the highest past J-month returns. The pure contrarian arbitrage portfolio (LL-LW) longs the long-term losers and shorts the long-term winners. Portfolios are held for a $K$-month holding period, where $K=3,6$, 9 , or 12 months. 
Following Fama and French (1996) and consistent with recent contrarian studies, ${ }^{3}$ we keep a 12-month gap between the end of the $J$-month formation period and the beginning of the K-month holding period for this particular strategy. Fama and French (1996) find that skipping the first 12 months after the end of the formation period produces stronger contrarian results because this method helps avoid long-term reversals being offset by the short-term continuation of returns. Their approach is consistent with DeBondt and Thaler (1985) which reports that the first year of their holding period did not produce significant contrarian profits.

\subsection{Late-stage contrarian strategy}

With a pure contrarian strategy, the investor is long a portfolio of long-term losers and short a portfolio of long-term winners. Although the profitability of such a strategy relies on these portfolios reversing their recent performance in the future, the securities in these portfolios may not be equally ready to reverse. Fama and French's (1996) use of a 12-month gap between the end of the formation period and the beginning of the holding period can be seen as an attempt to better select portfolios ready to reverse. Their approach may reduce continuation effects that would otherwise lead to lower contrarian profits. However, a problem with extending the gap to 12 months is that those securities that were ready to reverse at the end of the formation period may no longer be reversing as strongly at the end of the 12month wait. In addition, other securities may still not be ready to reverse, even after a 12month gap. That is, although having a 12-month gap may improve contrarian profitability to some extent, this may not be the most effective way to identify securities that are ready to reverse.

We can enhance the pure contrarian strategy if we can select a subset of the longterm losers (winners) that are more likely to reverse and do well (poorly) in the immediate

\footnotetext{
${ }^{3}$ Figelman (2007) and Grinblatt and Moskowitz (2004) skip one year, while George and Hwang (2004) allow 12-, 24-, 36-, and 48-month gaps between formation and holding.
} 
future. This selection is done on the basis of the recent short-term performance of the longterm losers and winners. Intuitively, those long-term losers (winners) that have recently performed relatively better (worse) than other long-term losers (winners) seem the obvious candidates to select for an enhanced contrarian strategy. We call this the late-stage contrarian strategy. Such indices either appear to have begun to reverse their long-term performance or seem more likely to begin reversing their long-term performance in the near future. Here, the term late-stage is being used in the sense that the extreme long-term performances of these indices may be about to end. It is expected that strategies based on late-stage contrarian indices will outperform the corresponding pure contrarian strategy because many indices that are not yet ready to reverse have been eliminated from the latestage contrarian strategies.

The late-stage strategy and portfolios are constructed as double dependent sorts as follows. The first sort is as described for the pure contrarian strategy. That is, at the beginning of each month the indices are ranked based on their past $J$-month returns $(J=36$, 48 , or 60 months). At the beginning of each month the long-term loser (LL) portfolio consists of the $25 \%$ of indices that have the lowest past $\mathrm{J}$-month returns, and the long-term winner (LW) portfolio is comprised of the $25 \%$ of indices that have the highest past $J$-month returns. These two portfolios are then each split into halves based on their component indices' most recent $J 2$-month returns, for $J 2=3,6,9$, or 12 months. These $J 2$-month returns are calculated from the most recent $\mathrm{J} 2$ months within the $\mathrm{J}$-month formation period. The latestage strategy is based on two of these four sub-portfolios. Specifically, let LLSW denote the portfolio composed of the $50 \%$ of the long-term loser indices LL with the largest $\mathrm{J} 2$-month returns (SW indicating short-term winner). Similarly, let LWSL denote the portfolio with the $50 \%$ of indices in the long-term winner portfolio LW that have the lowest past short-term J2-month returns (SL indicating short-term loser). This means that in the developed markets case with only 18 indices, for example, the long-term loser and long-term winner portfolios each contains four indices, while the late-stage portfolios LLSW and LWSL each contains two indices. 
The late-stage contrarian strategy buys the long-term losers with relatively good recent short-term returns (LLSW) and sells the long-term winners with relatively poor recent short-term returns (LWSL), denoted LLSW-LWSL. This is the enhanced contrarian strategy. By including only those indices that appear ready to reverse or that have already begun to reverse, this strategy is expected to be more profitable than the corresponding pure contrarian strategy.

As with the pure contrarian single-sort strategy, portfolios are held for a K-month holding period, where $K=3,6,9$, or 12 months. The late stage strategy is designed to avoid the problem of the evidence of long-term reversal being offset by the short-term continuation of returns. Thus, there is no need to skip 12 months between the end of the formation period and the beginning of the holding period, as was the case for pure momentum. Accordingly, the late stage strategy has only a one-month gap between the end of the formation period and the beginning of the holding period. Figure 1 provides a graphical representation of the relation between the formation and holding periods for the various strategies.

We adopt Jegadeesh and Titman's (1993) overlapping portfolio approach for holding period returns for all strategies (pure and late stage). In their approach, the reported average monthly return for the $K$-month holding period is an equal-weighted average of portfolio returns from the current month and the previous $K-1$ months. For example, for each month the LL monthly return for a three-month holding period is an equal-weighted average of the portfolio returns for the current month from the current month's LL portfolio, last month's LL portfolio, and the LL portfolio from two months ago. ${ }^{4}$ Note that overlapping the portfolios in this way ensures that the resulting monthly returns are non-overlapping, allowing the use of simple $t$-statistics. This popular method was introduced by Jegadeesh and Titman (1993) to increase test power. To facilitate comparisons between the single and double strategies, the discussion will focus on strategies with six-month holding periods $(K=6)$, with other results shown for robustness purposes.

\footnotetext{
${ }^{4}$ See Jegadeesh and Titman (1993) for a more detailed description of their approach.
} 
Discussion of post-holding period behavior will be based on annual event-time returns. These are averages of the 12-month returns for each portfolio for the first five years following the portfolio formation date. The associated $t$-statistics are based on the NeweyWest (1987) autocorrelation correction because the 12-month returns overlap as a result of monthly revisions of the portfolios.

\section{Analysis of results}

This section discusses the empirical results of our study. It includes raw and riskadjusted results for both the pure contrarian and late-stage contrarian strategies and concludes with a discussion of these strategies' subperiod results.

\subsection{Pure contrarian results}

Table 2 reports the returns of the short, long, and long-short portfolios for developed markets (Panel A) and emerging markets (Panel B) for several $(J, K)$ combinations. The contrarian strategy buys the long-term loser (LL) portfolio and sells the long-term winner (LW) portfolio to form a neutral portfolio LL-LW. These portfolios are based on past $J$-month returns $(J=36,48$, or 60$)$. Column 3 of Table 2 shows the $J$-month average formation period return in percentages for the long-term winner and loser portfolios. Columns 4 through 7 report the equal-weighted average monthly returns in percentages over the $K$-month holding periods $(K=3,6,9$, or 12$)$.

The developed markets results in Panel A of Table 2 show significant pure contrarian profits for all $(J, K)$ combinations, with the exception of $(J=36, K=9)$ and $(J=36, K=12)$. For example, with a 60-month formation period $(J=60)$, past long-term losers gain an average of $1.31 \%$ per month over the six-month holding period $(K=6)$. Past long-term winners gain an average of only $0.86 \%$ per month over the same period. The difference between LL and LW is $0.46 \%$ per month ( $t$-stat 2.28$)$.

The emerging markets results in Panel B of Table 2 are very different. Although all the emerging markets' pure contrarian profits in Panel B are larger than those of the 
corresponding developed markets in Panel A, none of the emerging markets' profits are statistically significant. For example, the strongest pure contrarian profit in Panel B using sixmonth holding periods $(J=60, K=6)$ is $0.68 \%$ per month. This return is only weakly significant (t-stat 1.69).

While this lack of significance in the face of larger profits is partly driven by the shorter sample length of the emerging market indices (since the earliest $\mathrm{MSCl}$ emerging market return series only begins in January 1988 rather than in January 1970) and partly by the higher volatility of the emerging markets portfolios compared to the developed markets portfolios, there is another issue to consider. Recall that our pure contrarian strategy skips 12 months between the end of the formation period and the beginning of the holding period. To check whether skipping 12 months is beneficial, we find in a separate analysis (not shown) that if we only skip one month, then (i) none of the developed market profits are significant but (ii) the emerging markets profits become larger for $J=48$ and $J=60$, with three combinations becoming significant. These inconsistent results reinforce our view that skipping 12 months may not be the best way to detect a contrarian effect when it is present.

Finally, the results in both panels of Table 2 show that for six-month holding periods the largest strategy returns are produced by 60 -month formation periods. For this reason, the next section focuses on whether the late-stage strategy can outperform the pure contrarian strategy with $J=60$ and $K=6$. The latter strategy will be our base case pure contrarian strategy in the remainder of this paper.

\section{[Table 2 about here]}

\subsection{Late-stage results}

The aim of this paper is to investigate whether contrarian strategies can be enhanced by consideration of the recent short-term performance of long-term winners and losers. The late-stage contrarian strategy is based on those long-term losers (winners) that have recently begun to perform relatively better (worse). Late-stage contrarian strategies are expected to outperform pure contrarian ones because many indices not yet ready to reverse are eliminated from late-stage contrarian strategies. 
The results for the late-stage contrarian strategies are presented in Table 3 for developed markets (Panel A) and emerging markets (Panel B). To conserve space, only combinations based on the past $J=60$ months' formation periods and for $J 2=3,6,9$, and 12 months are presented.

The average monthly returns of the late-stage strategy (LLSW-LWSL) are positive for all formation and holding periods. The late-stage strategy with six-month holding periods produces significant profits for $\mathrm{J} 2=6,9$, and 12 in Panel A of Table 3. For example, applying the late-stage strategy to developed markets with $J / J 2=60 / 6$ and $K=6$ produces a return of $0.58 \%$ per month ( $t$-stat 2.48 ). This result is somewhat larger than the corresponding pure contrarian base case LL-LW return of $0.46 \%$ per month ( $t$-stat 2.28 ) reported in Panel $A$ of Table 2.

The biggest improvement in performance comes from implementing late-stage strategies in emerging markets. Panel B reports significant late-stage profits with six-month holding periods $(K=6)$ and $J 2=3,6$, and 9. For example, the late-stage strategy with $J / J 2=60 / 6$ and $K=6$ produces a return of $1.24 \%$ per month ( $t$-stat 2.47$)$. In contrast, the corresponding pure contrarian base case LL-LW return reported in Panel B of Table 2 is only $0.68 \%$ per month and only weakly significant ( $t$-stat 1.69$)$.

More generally, comparing the results in Table 3 with those in Table 2 shows that the late-stage strategy profits with $J 2=6$ or 9 are always larger than the corresponding pure contrarian profits for both developed and emerging markets. The sections that follow frequently use the particular late-stage strategy with $J / J 2=60 / 6$ and $K=6$ as our late-stage base case in comparisons with the pure contrarian base case strategy with $J=60$ and $K=6$.

[Table 3 about here]

\subsection{Post-holding period returns of contrarian strategies}

Table 3 provides strong evidence of reversal of long-term returns for both developed and emerging markets. Since the duration of this reversal is likely to exceed the length of the holding periods used in our contrarian strategies, the question arises as to how long such reversals continue. The last five columns in Tables 2 and 3 present the average annual 
returns for each portfolio for the five 12-month periods following the formation date, together with the associated $t$-statistics based on the Newey-West (1987) autocorrelation correction up to lag 11. For the pure contrarian strategies in Table 2 we see that all five years have positive LL-LW returns, with the exception of Year 5 for the emerging market strategy with 48-month formation periods. Although most are not statistically significant, these positive returns indicate that prices continue to reverse throughout the first five years of the postformation period. Overall, the results in Tables 2 and 3 confirm the contrarian hypothesis first presented by DeBondt and Thaler (1985) and are consistent with other studies, such as that of Richards (1997), that have observed contrarian effects between international equity indices.

To better illustrate the post-formation behavior of the strategies' profits for the developed markets case, Figure 2 charts the post-formation cumulative returns of the latestage portfolio LLSW-LWSL (with $\mathrm{J} / \mathrm{J} 2=60 / 6$ ) and of the pure contrarian portfolio LL-LW (with $J=60$ ) using non-overlapping portfolios $(K=1)$ for the 60 months following the end of the formation period. The reversal of long-term returns that produces the contrarian profits for both strategies appears to slow considerably after about 40 months post-formation. Figure 3 displays the corresponding graphs for the emerging markets case. In this case, the graphs show that the reversal of long-term returns continues relatively consistently for 60 months post-formation.

[Figures 2 and 3 about here]

\subsection{Risk adjustments}

To determine whether the profits of these strategies should be considered a reward for bearing risk, the profits of the pure and late-stage contrarian strategies are risk adjusted using the two-factor time-series regression model employed by Balvers and Wu (2006). The two-factor model contains a market factor and a value minus growth factor (VMG) as follows:

$$
R_{p t}-R_{f t}=\alpha_{p}+\beta_{p}\left(R_{w t}-R_{f t}\right)+v_{p} V M G_{t}+\varepsilon_{p t}
$$


where the dependent variable $R_{p t}-R_{f t}$ is the monthly excess return of the equally weighted portfolio $p, R_{p t}$ represents the monthly US dollar return of portfolio $p$ at time $t$, and $R_{f, t}$ is the monthly risk-free rate at time $t$ represented by the one-month US T-Bill return. The independent variables or factors are as follows: $R_{w t}-R_{f t}$ corresponds to the excess return on the MSCI World Market index at time $t$; and $V M G_{t}$, or value minus growth, is the return on the $\mathrm{MSCI}$ World Value Index minus the return on the MSCI World Growth Index at time $t$. (A size factor is not included because $\mathrm{MSCl}$ country indices involve only large liquid stocks.)

The monthly values for the MSCI World Market index as well as the world value and growth indices are downloaded from the $\mathrm{MSCl}$ website. ${ }^{5}$ Ibbotson and Associates' onemonth T-Bill risk-free rate covering the full sample period from January 1970 to January 2011 was downloaded from Kenneth French's website. ${ }^{6}$ The two-factor model risk adjustment covers the period from January 1975 to January 2011 since the value and growth indices' price history starts in 1975 . The coefficients $\beta_{p}$, and $v_{p}$ are the regression loadings corresponding to the factors of the model, while the intercept $\alpha_{p}$ (or simply alpha) represents the risk-adjusted annualized abnormal return of the portfolio over the estimation period. If alpha is statistically significantly different from zero, then this is evidence of abnormal profits. The $t$-values corresponding to the regression coefficients are corrected for heteroskedasticity using White's (1980) test.

Table 4 reports the regression coefficients of the two models and the corresponding White-corrected $t$-values for the long, short, and long-short portfolios for the pure contrarian $(J=60$ and $K=6)$ and late-stage contrarian $(J / J 2=60 / 6$ and $K=6)$ base case strategies in Panels A and B, respectively. Developed markets results are reported in Section 1 of Table 4, while emerging markets results are reported in Section 2. Column 2 of Table 4 shows the unadjusted (raw) average monthly returns in percent for the portfolios, while column 3 shows the monthly alphas in percent from the two-factor model.

\footnotetext{
${ }^{5}$ At http://www.mscibarracom/products/indices/stindex.

${ }^{6}$ At http://www.mba.tuck.dartmouth.edu/pages/faculty/ken.french/data_library.
} 
Consider first the developed markets results in Section 1 of Table 4. For the pure contrarian strategy in Panel $A$, the risk-adjusted return of the arbitrage LL-LW portfolio is a significant $0.507 \%$ per month ( $t$-stat 2.46$)$ and slightly bigger than the unadjusted return of $0.46 \%$ per month. The late-stage strategy LLSW-LWSL alpha of $0.604 \%$ per month in Panel $B$ is also significant ( $t$-stat 2.54 ), and is larger than the $0.58 \%$ unadjusted monthly return.

In the emerging markets case in Section 2 of Table 4, the pure contrarian LL-LW alpha is $0.73 \%$ per month but is only significant at the $10 \%$ level (t-stat 1.84$)$. In contrast, the late-stage LLSW-LWSL alpha is significant (t-stat 2.54) and is almost twice as large as the corresponding pure contrarian alpha $(1.261 \% \vee 0.73 \%)$.

[Table 4 about here]

Another important feature of the evidence in Table 4 is that, in every instance, the long side of every strategy (LL or LLSW) has a significant alpha but none of the alphas of any of the strategies' short sides (LW or LWSL) are significant. Clearly it is the reversal of long-term losers that is producing much of these strategies' abnormal returns.

In summary, the risk-adjusted results in Table 4 support our expectation that the latestage strategy should outperform the corresponding pure contrarian strategy. Our results also show that the two-factor model does not capture the reversal of long-term returns in developed and emerging market indices.

\subsection{Subperiod analysis}

As a robustness check, we examine the performance of the pure and late-stage strategies in two subperiods. The first subperiod covers January 1970 to December 1989 (240 months) and the second subperiod extends from January 1990 to January 2011 (253 months). These subperiods split the developed markets sample into approximately equal halves.

Table 5 reports the profitability of the strategies for the developed markets case in the first subperiod in Panel A and in the second subperiod in Panel B. To conserve space, only the base case of each strategy is presented $(J=60$ months for the pure contrarian strategy and $J / J 2=60 / 6$ months for the late-stage strategy). Panel A of Table 5 confirms the 
profitability of the late-stage contrarian strategy in the first subperiod by showing significant returns for all holding periods. For example, the late-stage strategy with a six-month holding period $(K=6)$ produces a significant return of $1.15 \%$ per month $(t$-stat 2.76$)$. In contrast, the corresponding pure contrarian return of $0.44 \%$ per month is not significant ( $t$-stat 1.22$)$. The pure contrarian strategy only produces a significant profit in one case $(K=12)$. Nevertheless, the annual event time returns for the pure contrarian LL-LW portfolio is $11.07 \%$ ( $t$-stat 2.61$)$ for Year 1 and $13.80 \%$ for Year 2 (t-stat 3.08). This suggests that there is an underlying contrarian effect in the first subperiod that does not reliably lead to significant results when the overlapping portfolio technique is employed. Panel $A$ is consistent with the earlier fullsample results in the sense that the late-stage profits are larger than the corresponding pure contrarian profits.

[Table 5 about here]

Panel B of Table 5 presents dramatically different results for the second subperiod. Profitability for both the pure and late-stage strategies in this subperiod is close to zero in every case. For example, the pure contrarian strategy profit of $0.07 \%$ per month $(t$-stat 0.28$)$ is matched by the corresponding late-stage strategy with a profit of only $0.07 \%$ per month ( $t$ stat 0.24$)$. The annual event time returns in Panel B for the pure contrarian strategy support the holding period evidence that there is no cross-sectional contrarian effect for developed markets in the second subperiod. The LL-LW event time average returns range from a low of $-2.59 \%$ per year to a maximum of $1.74 \%$ per year and none are significant. This explains the lack of profitability of the late-stage strategy. If there is no underlying contrarian effect in the data being analyzed, then the late-stage strategy will be just as ineffective as the pure contrarian strategy.

For completeness, the developed markets subperiod returns with six-month holding periods $(K=6)$ reported in Table 5 are risk adjusted using the two-factor model described in the previous section. These results are presented in Table 6. Panel A shows the regression coefficients for the risk-adjusted returns in the first subperiod, from January 1970 to December 1989. The pure contrarian strategy's alpha of $0.763 \%$ per month is larger than for 
the full sample, but only significant at the $10 \%$ level ( $t$-statistic 1.85). Although only weakly significant, this alpha is considerably larger than the unadjusted return of $0.44 \%$ per month shown in column 2. In contrast, the late-stage strategy's risk-adjusted returns are statistically significant, with an alpha of $1.284 \%$ per month ( $t$-statistic 2.54$)$.

[Table 6 about here]

Risk-adjusted results for the second subperiod are reported in Panel B of Table 6. Consistent with the insignificant raw returns of Panel B of Table 5, the second subperiod alphas for both strategies are close to zero and insignificant. In short, the subperiod analysis identifies a strong contrarian effect in the first subperiod but is unable to detect a contrarian effect in the period from January 1990 to January 2011.

Before further investigating this apparent lack of a contrarian effect in the second subperiod for developed markets, we note that the emerging markets sample period is not long enough for a meaningful subperiod analysis because the emerging markets sample only begins in 1988 and is thus only two years longer than the developed markets second subperiod. ${ }^{7}$

\section{Longitudinal analysis}

We have seen that cross-sectional contrarian strategies do not detect long-term reversals in the developed markets indices for the period January 1990 to January 2011. If contrarian profits are the result of mispricing, then perhaps the increased tendency toward globalization and the integration of equity markets in recent years has allowed arbitrageurs to remove any mispricing. Another possibility is that there are reversals present that the crosssectional approach fails to detect. The latter possibility is investigated in this section.

The integration of equity markets, together with the increasing ease with which investors in many countries are able to invest globally through country funds and exchange-

\footnotetext{
${ }^{7}$ We can report a strong contrarian effect for the emerging markets in the second subperiod (from January 1990 to January 2011). The results are similar to what has already been observed for the full sample (results available on request).
} 
traded funds, means that developed markets have become more correlated recently than was the case in earlier times. If long-term returns in the developed markets become sufficiently synchronized, then similar reversals in many of these markets may be occurring at the same time. In such circumstances, going long some markets and short others could fail to identify common reversals. In other words, cross-sectional approaches such as the pure contrarian and late-stage contrarian strategies are not suited to detect reversals that occur simultaneously in each market.

If synchronized reversals are present in the developed markets, then we should be able to detect them longitudinally in the returns of the average developed market. ${ }^{8}$ To investigate this possibility, we define the DEV portfolio as the equal-weighted average of the $18 \mathrm{MSCl}$ developed market indices and calculate its monthly returns. If developed markets experience reversals that are synchronized across these markets, then the DEV returns that follow poor long-term performance would be expected to be larger, on average, than the DEV returns that follow good long-term returns.

Our testing procedure is as follows. The past five-year return of the DEV portfolio is calculated each month. These rolling five-year returns are ranked separately for each subperiod. Past five-year returns in a subperiod are categorized as low returns (LO) if they rank in the smallest $25 \%$ of five-year returns for that subperiod. Similarly, past five-year returns in a subperiod are categorized as high returns $(\mathrm{HI})$ if they rank in the largest $25 \%$ of five-year returns for that subperiod. We calculate the average DEV annual return for each of the first five years (denoted Year 1, Year 2,..,Year 5) that follow the end of each five-year period for each category (LO and $\mathrm{HI}$ ) separately. Each annual spread (denoted LO-HI) is the difference between the $\mathrm{LO}$ and $\mathrm{HI}$ average returns for that year. If there are substantial simultaneous reversals across the developed markets, then we would expect this spread to be significantly positive. The second subperiod is the best candidate for such evidence

\footnotetext{
${ }^{8}$ By investigating the average index rather than each index separately, we avoid some of the noise in the individual indices and can therefore test more powerfully for evidence of simultaneous reversals. The drawback is that we do not identify the degree to which each market experiences reversals, if evidence of a common reversal is found.
} 
because the existence of large cross-sectional profits in the first subperiod (see Table 5) effectively rules out the possibility that the developed markets were highly synchronized in the first subperiod.

The LO (HI) average used in the calculation of the LO-HI spread statistic is an average of annual returns that overlap to varying degrees because the length of time between the end of one LO $(\mathrm{HI})$ period and the next could be as little as one month or could be many years. Consequently, standard testing methods using $t$-tests are not available. To determine the statistical significance of the LO-HI spreads (and also the Sharpe ratio spreads described below), we employ a nonparametric Fisher randomization test that is applied by Kim, Nelson, and Startz (1991). The randomization test provides valid small-sample inferences, even when standard test assumptions do not hold. In particular, the randomization test gives valid small-sample inferences in the presence of heteroskedasticity and non-normality. It differs in practice from the corresponding bootstrap test only because it is based on sampling without replacement. Noreen (1989) provides a clear explanation of randomization test methods. The randomization $p$-values in this paper are based on twosided tests and 5,000 permutations.

Table 7 reports the $\mathrm{LO}, \mathrm{HI}$, and LO-HI average annual DEV returns for the first subperiod in Panel A and for the second subperiod in Panel B in columns 2 to 6 . None of the LO-HI spreads in the first subperiod are statistically significant, with average annual spreads ranging from only $0.43 \%$ to $15.11 \%$. In marked contrast, the second subperiod results reported in Panel B indicate strong evidence of reversal in DEV returns. Specifically, the return in the first year following a LO period is a significant $31.94 \%$ ( $p$-value 0.01 ) larger, on average, than the return in the first year following a $\mathrm{HI}$ period. Similarly, the Year $2 \mathrm{LO}-\mathrm{HI}$ spread of $28.12 \%$ in Panel B is also large and significant ( $p$-value 0.02). The Year 3 spread of $19.23 \%$ is large but not statistically significant.

Overall, the results in Table 7 show that significant long-term reversals do occur in the second subperiod in developed markets. There is a symmetric pattern to the combined results from Tables 5 and 7 . The evidence of reversal in the first subperiod is cross-sectional 
but not longitudinal, whereas the evidence of reversal in the second subperiod is longitudinal but not cross-sectional. ${ }^{9}$ Greater synchronicity between developed markets in the second subperiod than in the first is all that is needed to produce such a pattern.

[Table 7 about here]

Finally, we consider whether the substantial LO-HI spreads in Panel B of Table 7 could be a reward for bearing risk. Perhaps the higher average returns following LO periods can be explained by such returns having greater risk. One way to address this issue is to compare the Sharpe ratios of the returns following LO and HI periods. The final five columns of Table 7 report the Sharpe ratios of annual DEV returns in percentages for each of the first five years that follow the end of each five-year ranking period for each category (LO and $\mathrm{HI}$ ). For Year 1 to Year 5, the statistic of interest in each case is the Sharpe ratio of the annual returns following LO periods less the Sharpe ratio of the annual returns following $\mathrm{HI}$ periods. We denote these Sharpe ratio spreads $S_{L O}-S_{H I}$. From Panel A of Table 7, we see that none of these spreads in the first subperiod are significant. Panel B tells a different story for the second subperiod. While the Year 1 Sharpe spread of 1.47 is only weakly significant ( $p$-value 0.07 ), both the Year 2 Sharpe spread of 2.39 and the Year 3 Sharpe spread of 3.89 are significant ( $p$-values 0.01 and 0.00 , respectively). In short, there is no straightforward riskbased explanation for the large LO-HI spreads observed in the second subperiod.

\subsection{Implications of the results}

In summary, there is evidence of reversals of the long-term returns of both the developed and emerging equity markets. The cross-sectional late stage contrarian strategy produces significant profits when applied separately to the full samples of developed and emerging market indices. However, further subperiod analysis for the developed markets case finds large contrarian cross-sectional profits in the first subperiod but not in the second subperiod.

\footnotetext{
${ }^{9}$ Although we do not expect that the emerging markets have become sufficiently synchronized for them to exhibit a common reversal effect given the strong emerging markets cross-sectional effect, for completeness we conducted a similar longitudinal analysis on the average emerging market index for the second subperiod (January 1990 to January 2011). None of the resulting LO-HI differences for Years 1 to 5 are significant.
} 
Our conjecture that greater synchronization in the long-term returns of developed markets in the second subperiod may be making evidence of reversal difficult to detect using crosssectional approaches is supported by the results of our longitudinal analysis. We find strong evidence of a common reversal effect in the developed markets in the second subperiod but not in the first.

One implication of our results for investment strategies in the developed markets is that, while there is evidence of reversal in long-term returns, the recent subperiod evidence suggests that such reversals are best utilized for asset allocation and market timing decisions. Investors employing cross-sectional contrarian trading strategies in the developed markets in the future seem likely to be disappointed with their results. In the case of the emerging equity market indices, cross-sectional contrarian strategies have been significantly profitable. Yet investors in emerging market indices seeking to exploit this opportunity should be wary that increasing globalization and market integration may eventually mean that the emerging markets indices long-term returns will become more synchronized, leading to lower cross-sectional profitability in the future.

\section{Final comments and conclusion}

Cross-sectional contrarian strategies of the type used by DeBondt and Thaler (1985) can be used to demonstrate a contrarian effect in security returns. However, uncovering evidence of long-term return reversal can be difficult if there is short-term continuation offsetting long-term reversal. The late-stage contrarian strategy introduced in this paper is designed to better detect underlying long-term reversals by selecting those contrarian securities with long-term performances that appear more ready to reverse. In tests on developed and emerging market indices, we find that the late-stage contrarian strategy is consistently more profitable than the conventional pure contrarian strategy. As a result, in the emerging markets case the late-stage strategy is able to uncover a significant contrarian effect that the pure contrarian approach could not. Moreover, the contrarian effects in the $\mathrm{MSCl}$ indices are large. For example, the late-stage strategy produces significant risk- 
adjusted returns of $0.60 \%$ per month in the developed markets case and $1.26 \%$ per month in the emerging markets case when applied to the full sample.

An interesting feature of the data is that the developed market indices do not produce significant (cross-sectional) contrarian profits in the post-1989 subsample. How should such a result be interpreted? There are two potential explanations: Either long-term return reversals are not significant in this subsample or the developed markets had become so correlated during this period that the reversals in the different markets could not be detected using cross-sectional strategies. Our analysis supports the latter explanation. Employing a longitudinal approach, we find strong evidence of the reversal of long-term returns in the post-1989 subsample of developed markets. 


\section{References}

Balvers, R., Wu, Y., \& Gilliand, E. (2000). Mean Reversion Across National Stock Markets and Parametric Contrarian Investment Strategies. Journal of Finance, 55(2), 745-772.

Balvers, R. J., \& Wu, Y. (2006). Momentum and Mean Reversion Across National Equity Markets. Journal of Empirical Finance, 13, 24-48.

Chopra, N., Lakonishok, J., \& Ritter, J. R. (1992). Measuring Abnormal Performance: Do Stocks Overreact? Journal of Financial Economics, 31(2), 235-268.

DeBondt, W., \& Thaler, R. (1985). Does the Stock Market Overreact? Journal of Finance, 40, 793-808.

DeBondt, W., \& Thaler, R. (1987). Further Evidence on Investor Overreaction and Stock Market Seasonality. Journal of Finance, 42, 557-581.

Fama, E. F., \& French, K. R. (1996). Multifactor Explanation of Asset Pricing Anomalies. Journal of Finance, 51(1), 55-84.

Figelman, I. (2007). Stock Return Momentum and Reversal. Journal of Portfolio Management, 34(1), 51-67.

George, T. J., \& Hwang, C.-Y. (2004). The 52-Week High and Momentum Investing. Journal of Finance, 59(5), 2145-2176.

Grinblatt, M., \& Moskowitz, T. J. (2004). Predicting Stock Price Movements from Past Returns: The Role of Consistency and Tax-loss Selling. Journal of Financial Economics, 71(3), 514-579.

Jegadeesh, N., \& Titman, S. (1993). Returns to Buying Winners and Selling Losers: Implications for Stock Market Efficiency. Journal of Finance, 48(1), 65-91.

Kim, M. J., Nelson, C. R., \& Startz, R. (1991). Mean reversion in stock prices? A reappraisal of the empirical evidence. Review of Economic Studies, 58, 515-528.

Newey, W. K., \& West, K. D. (1987). A Simple, positive semi-definite, heteroskedasticity and autocorrelation consistent covariance matrix. Econometrica, 55, 703-708.

Noreen, E. W. (1989). Computer-Intensive Methods for Testing Hypotheses: An Introduction. New York, NY: Wiley \& Sons.

Richards, A. J. (1997). Winner-Loser Reversal in National Stock Market Indices: Can They Be Explained? Journal of Finance, 52(5), 2129-2144.

Shen, Q., Szakmary, A. C., \& Sharma, S. C. (2005). Momentum and Contrarian Strategies in International Stock Markets: Further Evidence. Journal of Multinational Financial Management, 15, 235-255.

White, H. (1980). A Heteroskedasticity-Consistent Covariance Matrix Estimator and a Direct Test for Heteroskedasticity. Econometrica, 48, 817-838. 
Table 1

Summary Statistics of Stock Index Returns

\begin{tabular}{|c|c|c|c|c|c|}
\hline \multicolumn{6}{|c|}{ Panel A: Developed Markets } \\
\hline Country & $\begin{array}{c}\text { Mean } \\
\%\end{array}$ & $\begin{array}{c}\text { SD } \\
\%\end{array}$ & Country & $\begin{array}{c}\text { Mean } \\
\%\end{array}$ & $\begin{array}{c}\text { SD } \\
\%\end{array}$ \\
\hline Australia & 1.04 & 7.08 & Japan & 0.98 & 6.29 \\
\hline Austria & 0.99 & 6.75 & Netherlands & 1.16 & 5.63 \\
\hline Belgium & 1.09 & 6.01 & Norway & 1.27 & 8.00 \\
\hline Canada & 1.02 & 5.78 & Singapore & 1.31 & 8.41 \\
\hline Denmark & 1.23 & 5.68 & Spain & 1.02 & 6.77 \\
\hline France & 1.07 & 6.61 & Sweden & 1.38 & 7.06 \\
\hline Germany & 1.03 & 6.36 & Switzerland & 1.08 & 5.35 \\
\hline Hong Kong & 1.75 & 10.33 & UK & 1.04 & 6.49 \\
\hline \multirow[t]{2}{*}{ Italy } & 0.78 & 7.42 & US & 0.88 & 4.52 \\
\hline & & & AVERAGE & 1.12 & 6.70 \\
\hline \multicolumn{6}{|c|}{ Panel B: Emerging Markets } \\
\hline Country & $\begin{array}{c}\text { Mean } \\
\%\end{array}$ & $\begin{array}{c}\text { SD } \\
\%\end{array}$ & Country & $\begin{array}{c}\text { Mean } \\
\%\end{array}$ & $\begin{array}{c}\text { SD } \\
\%\end{array}$ \\
\hline Argentina & 2.59 & 15.81 & Malaysia & 1.10 & 8.49 \\
\hline Brazil & 2.80 & 15.16 & Mexico & 2.10 & 9.24 \\
\hline Chile & 1.78 & 7.10 & Morocco & 1.23 & 5.65 \\
\hline China & 0.55 & 10.70 & Pakistan & 1.16 & 11.29 \\
\hline Colombia & 1.86 & 9.44 & Peru & 2.00 & 9.55 \\
\hline Czech Republic & 1.53 & 8.59 & Philippines & 1.00 & 9.32 \\
\hline Egypt & 1.83 & 9.75 & Poland & 2.17 & 14.51 \\
\hline Hungary & 1.82 & 11.10 & Russia & 2.69 & 16.52 \\
\hline India & 1.27 & 9.05 & South Africa & 1.36 & 8.13 \\
\hline Indonesia & 1.96 & 14.79 & Sri Lanka & 1.27 & 10.89 \\
\hline Israel & 0.88 & 7.07 & Taiwan & 1.15 & 10.77 \\
\hline Jordan & 0.47 & 5.35 & Thailand & 1.29 & 11.20 \\
\hline \multirow[t]{2}{*}{ Korea } & 1.25 & 11.20 & Turkey & 2.31 & 16.95 \\
\hline & & & AVERAGE & 1.59 & 10.68 \\
\hline
\end{tabular}

This table provides descriptive statistics for the return data of the $18 \mathrm{MSCl}$ developed market and $26 \mathrm{MSCl}$ emerging market indices from their first available months (January 1970 for the developed markets and January 1988 at the earliest for the emerging markets) until January 2011, obtained from Datastream. The mean refers to the average monthly returns and SD refers to the standard deviation of monthly returns. 
Table 2

Profitability of the Pure Contrarian Strategy

\begin{tabular}{|c|c|c|c|c|c|c|c|c|c|c|c|}
\hline \multicolumn{12}{|c|}{ Panel A: Developed Markets } \\
\hline \multirow[b]{2}{*}{$J$} & \multirow[b]{2}{*}{ Portfolio } & \multirow{2}{*}{$\begin{array}{l}\text { Formation } \\
\text { Return }\end{array}$} & \multicolumn{4}{|c|}{ Holding Period Returns } & \multicolumn{5}{|c|}{ Annual Event Time Returns } \\
\hline & & & $K=3$ & $K=6$ & $K=9$ & $K=12$ & Year 1 & Year 2 & Year 3 & Year 4 & Year 5 \\
\hline \multirow[t]{6}{*}{36} & LW & 117.6 & 0.86 & 0.91 & 0.99 & 1.04 & 11.90 & 12.87 & 12.78 & 14.01 & 14.56 \\
\hline & & & $(3.22)$ & $(3.41)$ & (3.71) & $(3.88)$ & $(3.56)$ & $(3.00)$ & $(4.25)$ & $(4.26)$ & $(4.46)$ \\
\hline & LL & 0.0 & 1.29 & 1.28 & 1.34 & 1.35 & 15.13 & 17.48 & 17.72 & 16.39 & 17.17 \\
\hline & & & $(5.05)$ & $(5.09)$ & $(5.39)$ & $(5.53)$ & $(4.65)$ & $(4.94)$ & $(5.05)$ & $(4.27)$ & $(4.34)$ \\
\hline & LL-LW & & 0.43 & 0.37 & 0.35 & 0.31 & 3.23 & 4.61 & 4.94 & 2.38 & 2.61 \\
\hline & & & $(2.17)$ & $(2.01)$ & $(1.91)$ & $(1.73)$ & $(1.25)$ & $(2.21)$ & $(2.24)$ & $(1.23)$ & $(1.05)$ \\
\hline \multirow[t]{6}{*}{48} & LW & 153.9 & 0.88 & 0.90 & 0.94 & 0.93 & 12.74 & 12.03 & 10.92 & 13.16 & 14.97 \\
\hline & & & $(3.25)$ & (3.32) & $(3.45)$ & $(3.40)$ & $(3.70)$ & (3.71) & $(3.70)$ & $(4.08)$ & $(4.47)$ \\
\hline & LL & 6.7 & 1.28 & 1.30 & 1.32 & 1.32 & 16.12 & 17.52 & 16.85 & 16.90 & 15.72 \\
\hline & & & $(5.25)$ & (5.33) & $(5.43)$ & (5.39) & (5.01) & $(5.18)$ & $(4.31)$ & $(4.25)$ & $(4.15)$ \\
\hline & LL-LW & & 0.40 & 0.40 & 0.39 & 0.39 & 3.38 & 5.49 & 5.93 & 3.74 & 0.75 \\
\hline & & & $(2.00)$ & $(2.08)$ & $(2.01)$ & $(2.02)$ & $(1.44)$ & $(2.53)$ & $(2.37)$ & $(1.65)$ & $(0.36)$ \\
\hline \multirow[t]{6}{*}{60} & LW & 197.0 & 0.81 & 0.86 & 0.84 & 0.86 & 13.36 & 10.93 & 12.08 & 14.08 & 15.37 \\
\hline & & & $(2.90)$ & (3.09) & $(3.02)$ & (3.07) & $(4.03)$ & $(3.44)$ & (3.91) & $(4.23)$ & $(4.48)$ \\
\hline & LL & 15.5 & 1.32 & 1.31 & 1.30 & 1.31 & 16.58 & 16.88 & 16.70 & 16.38 & 17.26 \\
\hline & & & $(5.32)$ & $(5.28)$ & $(5.23)$ & $(5.32)$ & $(4.97)$ & (4.69) & $(4.28)$ & $(4.02)$ & $(4.19)$ \\
\hline & LL-LW & & 0.51 & 0.46 & 0.46 & 0.45 & 3.22 & 5.95 & 4.62 & 2.31 & 1.88 \\
\hline & & & $(2.48)$ & $(2.28)$ & $(2.30)$ & $(2.30)$ & $(1.32)$ & (2.57) & (1.81) & $(1.08)$ & $(0.81)$ \\
\hline \multicolumn{12}{|c|}{ Panel B: Emerging Markets } \\
\hline \multirow[b]{2}{*}{$J$} & \multirow[b]{2}{*}{ Portfolio } & \multirow{2}{*}{$\begin{array}{l}\text { Formation } \\
\text { Return }\end{array}$} & \multicolumn{4}{|c|}{ Holding Period Returns } & \multicolumn{5}{|c|}{ Annual Event Time Returns } \\
\hline & & & $K=3$ & $K=6$ & $K=9$ & $K=12$ & Year 1 & Year 2 & Year 3 & Year 4 & Year 5 \\
\hline \multirow[t]{6}{*}{36} & LW & 212.9 & 1.14 & 1.09 & 1.17 & 1.20 & 21.07 & 15.79 & 14.66 & 12.78 & 18.79 \\
\hline & & & $(2.35)$ & $(2.19)$ & $(2.36)$ & $(2.41)$ & $(3.44)$ & $(3.00)$ & $(2.22)$ & $(2.00)$ & $(2.95)$ \\
\hline & LL & -14.2 & 1.76 & 1.74 & 1.78 & 1.70 & 22.85 & 23.83 & 19.86 & 19.46 & 19.02 \\
\hline & & & (3.69) & (3.74) & $(3.88)$ & $(3.75)$ & $(3.73)$ & $(3.74)$ & $(3.14)$ & $(2.98)$ & $(2.75)$ \\
\hline & LL-LW & & 0.62 & 0.66 & 0.60 & 0.50 & 1.77 & 8.04 & 5.20 & 6.68 & 0.23 \\
\hline & & & $(1.63)$ & $(1.72)$ & $(1.62)$ & $(1.39)$ & $(0.37)$ & (2.13) & $(1.42)$ & (2.82) & $(0.06)$ \\
\hline \multirow[t]{6}{*}{48} & LW & 301.7 & 1.11 & 1.15 & 1.13 & 1.08 & 14.28 & 15.79 & 14.01 & 16.82 & 19.53 \\
\hline & & & $(2.17)$ & $(2.22)$ & $(2.15)$ & $(2.03)$ & $(2.35)$ & (2.41) & $(2.03)$ & $(2.53)$ & (2.64) \\
\hline & LL & -8.7 & 1.87 & 1.73 & 1.70 & 1.60 & 26.15 & 23.12 & 17.25 & 19.02 & 18.42 \\
\hline & & & (3.98) & (3.62) & (3.59) & (3.39) & $(4.00)$ & (3.35) & $(2.55)$ & $(2.77)$ & $(2.51)$ \\
\hline & LL-LW & & 0.76 & 0.57 & 0.58 & 0.52 & 11.87 & 7.33 & 3.24 & 2.20 & -1.11 \\
\hline & & & (1.87) & $(1.43)$ & $(1.46)$ & (1.35) & $(2.78)$ & $(1.62)$ & $(0.88)$ & $(0.71)$ & $(-0.21)$ \\
\hline \multirow[t]{6}{*}{60} & LW & 358.6 & 0.93 & 0.97 & 0.99 & 1.04 & 13.48 & 14.37 & 18.14 & 17.89 & 17.47 \\
\hline & & & $(1.70)$ & (1.79) & (1.83) & (1.91) & $(2.17)$ & $(2.07)$ & (2.59) & $(2.45)$ & $(2.16)$ \\
\hline & LL & -3.2 & 1.56 & 1.65 & 1.55 & 1.57 & 25.47 & 21.25 & 18.71 & 20.80 & 22.03 \\
\hline & & & (3.10) & (3.33) & (3.18) & (3.24) & (3.61) & $(2.96)$ & (2.59) & $(2.80)$ & $(2.78)$ \\
\hline & LL-LW & & 0.63 & 0.68 & 0.56 & 0.53 & 11.99 & 6.89 & 0.57 & 2.91 & 4.56 \\
\hline & & & (1.54) & (1.69) & $(1.44)$ & (1.38) & $(2.47)$ & (1.99) & $(0.17)$ & $(0.68)$ & $(0.91)$ \\
\hline
\end{tabular}

This table presents the average monthly holding period returns in percentages of the short, long, and arbitrage portfolios of the pure contrarian strategy for developed markets (Panel A) and emerging markets (Panel B). Portfolios are constructed as follows: At the beginning of each month $t$, indices are ranked based on their past $J$-month formation period returns for $J=36,48$, and 60 months. The long-term loser equal-weighted portfolio (LL) contains the $25 \%$ of indices with the lowest returns, and the long-term winner equal-weighted portfolio (LW) contains the $25 \%$ of indices with the largest returns. The strategy LL-LW longs the long-term loser portfolio and shorts the long-term winner portfolio to be held for $K=3,6,9$, or 12 months. Here Formation Return is the portfolio's J-month average formation period return in percentages. Annual event time returns (Year 1, Year 2, Year 3, Year 4, and Year 5) are the average annual returns in percentages for the first five years following the portfolio formation date. The $t$-statistics are presented in parentheses. Holding period $t$-statistics are simple $t$ statistics, whereas the annual event time $t$-statistics are based on the Newey-West (1987) correction for autocorrelation up to lag 11. 
Table 3

Profitability of the Late-Stage Contrarian Strategy

\begin{tabular}{|c|c|c|c|c|c|c|c|c|c|c|c|}
\hline \multicolumn{12}{|c|}{ Panel A: Developed Markets } \\
\hline \multirow[b]{2}{*}{$J$} & \multirow[b]{2}{*}{ J2 } & \multirow[b]{2}{*}{ Portfolio } & \multicolumn{4}{|c|}{ Holding Period Returns } & \multicolumn{5}{|c|}{ Annual Event Time Returns } \\
\hline & & & $K=3$ & $K=6$ & $K=9$ & $K=12$ & Year 1 & Year 2 & Year 3 & Year 4 & Year 5 \\
\hline \multirow[t]{24}{*}{60} & \multirow[t]{6}{*}{3} & \multirow[t]{2}{*}{ LWSL } & 1.13 & 0.99 & 0.94 & 0.92 & 11.87 & 11.08 & 11.78 & 14.58 & 15.11 \\
\hline & & & $(4.02)$ & $(3.56)$ & (3.34) & (3.290 & (3.32) & $(3.48)$ & (3.83) & $(4.44)$ & $(4.42)$ \\
\hline & & \multirow[t]{2}{*}{ LLSW } & 1.22 & 1.30 & 1.35 & 1.32 & 17.67 & 16.49 & 16.93 & 16.33 & 18.06 \\
\hline & & & $(4.56)$ & $(5.05)$ & $(5.26)$ & $(5.16)$ & $(5.01)$ & $(4.33)$ & $(4.12)$ & (3.79) & $(4.35)$ \\
\hline & & \multirow[t]{2}{*}{ LLSW-LWSL } & 0.10 & 0.31 & 0.41 & 0.40 & 5.80 & 5.41 & 5.15 & 1.75 & 2.95 \\
\hline & & & $(0.39)$ & $(1.37)$ & $(1.88)$ & $(1.88)$ & $(2.34)$ & $(2.25)$ & $(1.68)$ & $(0.59)$ & $(1.05)$ \\
\hline & \multirow[t]{6}{*}{6} & \multirow[t]{2}{*}{ LWSL } & 0.97 & 0.82 & 0.84 & 0.87 & 11.34 & 11.03 & 11.50 & 15.80 & 15.02 \\
\hline & & & (3.42) & $(2.90)$ & (2.98) & (3.11) & (3.10) & (3.63) & (3.49) & $(4.24)$ & $(4.68)$ \\
\hline & & \multirow[t]{2}{*}{ LLSW } & 1.34 & 1.40 & 1.43 & 1.40 & 18.99 & 16.56 & 17.13 & 15.88 & 17.95 \\
\hline & & & $(4.99)$ & $(5.37)$ & $(5.46)$ & (5.39) & $(5.02)$ & $(4.30)$ & $(4.21)$ & (3.74) & $(4.29)$ \\
\hline & & \multirow[t]{2}{*}{ LLSW-LWSL } & 0.37 & 0.58 & 0.59 & 0.53 & 7.65 & 5.53 & 5.63 & 0.08 & 2.93 \\
\hline & & & $(1.50)$ & $(2.48)$ & $(2.64)$ & $(2.45)$ & $(2.99)$ & $(2.17)$ & $(1.88)$ & $(0.03)$ & $(1.14)$ \\
\hline & \multirow[t]{6}{*}{9} & LWSL & 0.81 & 0.79 & 0.87 & 0.86 & 11.09 & 10.22 & 12.43 & 16.37 & 14.86 \\
\hline & & & $(2.85)$ & $(2.80)$ & (3.07) & (3.05) & (3.13) & (3.34) & (3.65) & $(4.47)$ & $(4.63)$ \\
\hline & & LLSW & 1.45 & 1.45 & 1.45 & 1.43 & 19.02 & 17.28 & 17.73 & 15.95 & 17.60 \\
\hline & & & $(5.34)$ & (5.39) & $(5.40)$ & (5.36) & (5.180 & $(4.40)$ & (4.35) & (3.93) & $(4.06)$ \\
\hline & & LLSW-LWSL & 0.64 & 0.66 & 0.59 & 0.57 & 7.92 & 7.06 & 5.30 & -0.41 & 2.74 \\
\hline & & & $(2.59)$ & $(2.82)$ & $(2.64)$ & $(2.65)$ & $(3.40)$ & (2.39) & $(1.88)$ & $(-0.15)$ & $(1.00)$ \\
\hline & 12 & LWSL & 0.93 & 0.93 & 0.95 & 0.91 & 11.75 & 10.30 & 12.01 & 16.85 & 14.75 \\
\hline & & & (3.35) & (3.31) & (3.37) & (3.24) & $(3.40)$ & (3.32) & $(3.48)$ & $(4.45)$ & $(4.56)$ \\
\hline & & LLSW & 1.42 & 1.38 & 1.39 & 1.37 & 17.99 & 17.46 & 18.10 & 16.21 & 16.73 \\
\hline & & & $(5.33)$ & $(5.18)$ & $(5.23)$ & $(5.20)$ & (5.09) & (4.39) & $(4.43)$ & $(4.01)$ & (3.96) \\
\hline & & LLSW-LWSL & 0.48 & 0.45 & 0.44 & 0.46 & 6.24 & 7.16 & 6.09 & -0.64 & 1.99 \\
\hline & & & $(2.02)$ & $(2.02)$ & $(2.07)$ & $(2.21)$ & $(2.72)$ & $(2.42)$ & $(2.10)$ & $(-0.24)$ & $(0.73)$ \\
\hline Pan & el B: & Emerging Mark & & & & & & & & & \\
\hline & & & Holdin & Period & Returns & & An & ual Ever & t Time $R$ & turns & \\
\hline J & J2 & Portfolio & $K=3$ & $K=6$ & $K=9$ & $K=12$ & Year 1 & Year 2 & Year 3 & Year 4 & Year 5 \\
\hline 60 & 3 & LWSL & 1.04 & 0.86 & 0.77 & 0.80 & 12.07 & 14.36 & 18.29 & 17.59 & 17.57 \\
\hline & & & $(1.85)$ & (1.57) & (1.41) & (1.49) & $(2.00)$ & $(2.13)$ & (2.61) & (2.43) & (1.98) \\
\hline & & LLSW & 2.01 & 1.95 & 1.94 & 1.71 & 25.87 & 19.74 & 18.71 & 19.69 & 20.88 \\
\hline & & & (3.64) & (3.56) & (3.57) & (3.19) & (3.58) & $(2.58)$ & $(2.53)$ & (2.68) & $(2.46)$ \\
\hline & & LLSW-LWSL & 0.97 & 1.09 & 1.17 & 0.91 & 13.80 & 5.38 & 0.42 & 2.10 & 3.31 \\
\hline & & & $(1.96)$ & $(2.35)$ & $(2.58)$ & $(2.02)$ & $(2.56)$ & $(1.28)$ & $(0.11)$ & $(0.46)$ & $(0.53)$ \\
\hline & 6 & LWSL & 0.66 & 0.59 & 0.77 & 0.84 & 11.58 & 15.62 & 17.34 & 16.95 & 18.94 \\
\hline & & & (1.11) & $(1.04)$ & (1.37) & $(1.50)$ & (1.95) & $(2.26)$ & $(2.54)$ & (2.25) & (1.99) \\
\hline & & LLSW & 1.89 & 1.83 & 1.81 & 1.68 & 23.82 & 21.91 & 19.29 & 19.07 & 24.20 \\
\hline & & & $(3.30)$ & (3.29) & (3.24) & (3.04) & (3.25) & $(2.86)$ & $(2.76)$ & (2.59) & (2.64) \\
\hline & & LLSW-LWSL & 1.23 & 1.24 & 1.04 & 0.85 & 12.23 & 6.29 & 1.95 & 2.12 & 5.26 \\
\hline & & & $(2.30)$ & $(2.47)$ & $(2.09)$ & $(1.74)$ & $(2.65)$ & $(1.43)$ & $(0.54)$ & $(0.42)$ & $(0.76)$ \\
\hline & 9 & LWSL & 0.60 & 0.69 & 0.81 & 0.87 & 12.63 & 14.34 & 17.79 & 16.62 & 19.75 \\
\hline & & & $(1.09)$ & $(1.28)$ & (1.51) & (1.63) & (2.11) & $(2.12)$ & (2.62) & (2.20) & $(2.14)$ \\
\hline & & LLSW & 2.05 & 1.86 & 1.76 & 1.68 & 24.62 & 22.77 & 17.39 & 18.52 & 25.44 \\
\hline & & & (3.65) & (3.36) & (3.19) & (3.09) & (3.34) & $(2.97)$ & $(2.57)$ & (2.35) & $(2.70)$ \\
\hline & & LLSW-LWSL & 1.45 & 1.17 & 0.95 & 0.80 & 11.99 & 8.43 & -0.40 & 1.90 & 5.69 \\
\hline & & & $(2.88)$ & $(2.37)$ & $(1.97)$ & $(1.74)$ & $(2.67)$ & $(1.97)$ & $(-0.11)$ & $(0.31)$ & $(0.73)$ \\
\hline & 12 & LWSL & 1.04 & 0.97 & 0.99 & 1.02 & 15.06 & 12.50 & 17.19 & 18.76 & 19.48 \\
\hline & & & (1.94) & $(1.80)$ & (1.85) & (1.92) & $(2.43)$ & (1.89) & $(2.45)$ & (2.24) & $(2.12)$ \\
\hline & & LLSW & 1.93 & 1.59 & 1.60 & 1.54 & 22.79 & 22.52 & 15.57 & 19.17 & 26.44 \\
\hline & & & (3.52) & $(2.93)$ & $(3.00)$ & (2.91) & (3.09) & $(2.93)$ & (2.29) & (2.33) & $(2.98)$ \\
\hline & & LLSW-LWSL & 0.88 & 0.62 & 0.61 & 0.52 & 7.72 & 10.02 & -1.62 & 0.41 & 6.95 \\
\hline & & & $(1.75)$ & $(1.30)$ & $(1.32)$ & $(1.17)$ & $(1.56)$ & $(2.43)$ & $(-0.39)$ & $(0.05)$ & $(0.99)$ \\
\hline
\end{tabular}


This table presents the average monthly holding period returns in percentages of the short, long and arbitrage portfolios of the late-stage contrarian strategy for developed markets (Panel A) and emerging markets (Panel B). Late-stage portfolios are derived from the 60-month formation period pure contrarian strategy $(J=60)$ long-term loser (LL) and long-term winner (LW) portfolios. The formation of the LL and LW portfolios is explained in Table 2. Within the LW portfolio and the LL portfolio, indices are further classified based on their J2-month return from the last $\mathrm{J} 2$ months of the 60 -month formation period for $\mathrm{J} 2=3,6,9$, or 12 . The $50 \%$ of LL indices with the best $\mathrm{J} 2$ month returns define the LLSW equal-weighted portfolio (long-term losers that are short-term winners). Similarly, the $50 \%$ of LW indices with the worst $J 2$-month returns define the LWSL portfolio (long-term winners that are short-term losers). The late-stage contrarian strategy LLSW-LWSL is held for $K=3,6,9$, and 12 months. Annual event time returns (Year 1, Year 2, Year 3, Year 4, and Year 5) are the average annual returns in percentages for a portfolio for the first five years following the portfolio formation date. The $t$-statistics are presented in parentheses. Holding period $t$-statistics are simple $t$-statistics, whereas the annual event time $t$-statistics are based on the Newey-West (1987) correction for autocorrelation up to lag 11. 
Table 4

Risk-Adjusted Pure Contrarian and Late-Stage Contrarian Profits

\begin{tabular}{|c|c|c|c|c|c|}
\hline \multicolumn{6}{|c|}{ Section 1: Developed Markets } \\
\hline \multicolumn{6}{|c|}{ Panel A: Pure Contrarian } \\
\hline \multirow[b]{2}{*}{ Portfolio } & \multirow{2}{*}{$\begin{array}{l}\text { Raw } \\
\text { Return }\end{array}$} & \multicolumn{4}{|c|}{ Two-Factor Model } \\
\hline & & $\alpha$ & $\beta$ & $\boldsymbol{v}$ & Adj $R^{2}$ \\
\hline LW & 0.86 & $\begin{array}{l}-0.147 \\
(-0.985)\end{array}$ & $\begin{array}{l}1.124 \\
(24.265)\end{array}$ & $\begin{array}{l}0.035 \\
(0.465)\end{array}$ & $72.4 \%$ \\
\hline LL & 1.31 & $\begin{array}{l}0.360 \\
(2.205)\end{array}$ & $\begin{array}{l}0.939 \\
(14.599)\end{array}$ & $\begin{array}{l}0.265 \\
(3.077)\end{array}$ & $62.4 \%$ \\
\hline LL-LW & 0.46 & $\begin{array}{l}0.507 \\
(2.463)\end{array}$ & $\begin{array}{l}-0.185 \\
(-2.375)\end{array}$ & $\begin{array}{l}0.293 \\
(2.054)\end{array}$ & $5.3 \%$ \\
\hline \multicolumn{6}{|c|}{ Panel B: Late-Stage } \\
\hline LWSL & 0.82 & $\begin{array}{l}-0.170 \\
(-1.025)\end{array}$ & $\begin{array}{l}1.130 \\
(21.101)\end{array}$ & $\begin{array}{l}0.058 \\
(0.671)\end{array}$ & $67.9 \%$ \\
\hline LLSW & 1.40 & $\begin{array}{l}0.434 \\
(2.392)\end{array}$ & $\begin{array}{l}0.938 \\
(16.685)\end{array}$ & $\begin{array}{l}0.354 \\
(3.181)\end{array}$ & $55.0 \%$ \\
\hline LLSW-LWSL & 0.58 & $\begin{array}{l}0.604 \\
(2.538) \\
\end{array}$ & $\begin{array}{l}-0.192 \\
(-2.394) \\
\end{array}$ & $\begin{array}{l}0.296 \\
(2.002)\end{array}$ & $4.6 \%$ \\
\hline
\end{tabular}

Section 2: Emerging Markets

\begin{tabular}{|c|c|c|c|c|c|}
\hline \multicolumn{6}{|c|}{ Panel A: Pure Contrarian } \\
\hline \multirow[b]{2}{*}{ Portfolio } & \multirow{2}{*}{$\begin{array}{l}\text { Raw } \\
\text { Return }\end{array}$} & \multicolumn{4}{|c|}{ Two-Factor Model } \\
\hline & & $\alpha$ & $\beta$ & $\boldsymbol{v}$ & Adj $R^{2}$ \\
\hline LW & 0.97 & $\begin{array}{l}0.253 \\
(0.666)\end{array}$ & $\begin{array}{l}1.263 \\
(11.639)\end{array}$ & $\begin{array}{l}0.197 \\
(1.134)\end{array}$ & $55.0 \%$ \\
\hline LL & 1.65 & $\begin{array}{l}0.983 \\
(2.580)\end{array}$ & $\begin{array}{l}1.014 \\
(12.422)\end{array}$ & $\begin{array}{l}0.180 \\
(0.720)\end{array}$ & $41.8 \%$ \\
\hline LL-LW & 0.68 & $\begin{array}{l}0.730 \\
(1.837)\end{array}$ & $\begin{array}{l}-0.248 \\
(-2.649)\end{array}$ & $\begin{array}{l}-0.017 \\
(-0.067)\end{array}$ & $2.9 \%$ \\
\hline \multicolumn{6}{|c|}{ Panel B: Late-Stage } \\
\hline LWSL & 0.59 & $\begin{array}{l}-0.148 \\
(-0.349)\end{array}$ & $\begin{array}{l}1.277 \\
(10.897)\end{array}$ & $\begin{array}{l}0.058 \\
(0.282)\end{array}$ & $49.1 \%$ \\
\hline LLSW & 1.83 & $\begin{array}{l}1.113 \\
(2.591)\end{array}$ & $\begin{array}{l}1.135 \\
(10.819)\end{array}$ & $\begin{array}{l}0.169 \\
(0.562)\end{array}$ & $40.2 \%$ \\
\hline LLSW-LWSL & 1.24 & $\begin{array}{l}1.261 \\
(2.538)\end{array}$ & $\begin{array}{l}-0.141 \\
(-1.140) \\
\end{array}$ & $\begin{array}{l}0.111 \\
(0.332)\end{array}$ & $0.0 \%$ \\
\hline
\end{tabular}

This table presents the two- and three-factor regression results for the monthly returns of the contrarian portfolios with $J=60$ and $K=6$ and the late-stage portfolios with $J / J 2=60 / 6$ and $K=6$. For the pure contrarian strategy, LW is the portfolio of long-term winners and LL is the portfolio of long-term losers (as described in Table 2). For the late-stage strategy, LWSL is the portfolio of long-term winners that have the worst short-term performance and LLSW is the portfolio of long-term losers with the best short-term performance (as described in Table 3). The two-factor regression is as follows:

$$
R_{p t}-R_{f t}=\alpha_{p}+\beta_{p}\left(R_{w t}-R_{f t}\right)+v_{p} V M G_{t}+\varepsilon_{p t}
$$

where $R_{w t}-R_{f t}$ is the excess return on the MSCI World Market portfolio and $V M G_{t}$ is the value growth factor represented by the return on the $\mathrm{MSCl}$ World Value Index minus the return on the $\mathrm{MSCl}$ World Growth Index. Raw Return is the unadjusted monthly percent return for the respective portfolio. The $t$-statistics presented in parentheses are corrected for heteroskedasticity using White's (1980) test. 
Table 5

Profitability for the Developed Markets in Subperiods

\begin{tabular}{|c|c|c|c|c|c|c|c|c|c|c|c|c|}
\hline \multirow[b]{2}{*}{$\mathbf{J}$} & \multirow[b]{2}{*}{ J2 } & \multirow[b]{2}{*}{ Portfolio } & \multirow{2}{*}{$\begin{array}{l}\text { Formation } \\
\text { Return }\end{array}$} & \multicolumn{4}{|c|}{ Holding Period Returns } & \multicolumn{5}{|c|}{ Annual Event Time Returns } \\
\hline & & & & $K=3$ & $K=6$ & $K=9$ & $K=12$ & Year 1 & Year 2 & Year 3 & Year 4 & Year 5 \\
\hline \multicolumn{13}{|c|}{ Panel A: Subperiod 1 (January 1970 to December 1989) } \\
\hline \multicolumn{13}{|c|}{ Pure Contrarian } \\
\hline \multirow[t]{3}{*}{60} & & LW & 230.6 & $\begin{array}{l}1.33 \\
(3.52)\end{array}$ & $\begin{array}{l}1.30 \\
(3.41)\end{array}$ & $\begin{array}{l}1.30 \\
(3.40)\end{array}$ & $\begin{array}{l}1.25 \\
(3.28)\end{array}$ & $\begin{array}{l}15.22 \\
(2.94)\end{array}$ & $\begin{array}{l}12.61 \\
(2.46)\end{array}$ & $\begin{array}{l}17.30 \\
(3.90)\end{array}$ & $\begin{array}{l}22.26 \\
(4.30)\end{array}$ & $\begin{array}{l}27.52 \\
(5.06)\end{array}$ \\
\hline & & LL & 13.5 & $\begin{array}{l}1.71 \\
(5.10)\end{array}$ & $\begin{array}{l}1.73 \\
(5.02)\end{array}$ & $\begin{array}{l}1.87 \\
(5.28)\end{array}$ & $\begin{array}{l}1.92 \\
(5.30)\end{array}$ & $\begin{array}{l}26.29 \\
(4.55)\end{array}$ & $\begin{array}{l}26.41 \\
(3.84)\end{array}$ & $\begin{array}{l}27.15 \\
(3.44)\end{array}$ & $\begin{array}{l}26.74 \\
(2.95)\end{array}$ & $\begin{array}{l}26.21 \\
(2.83)\end{array}$ \\
\hline & & LL-LW & & $\begin{array}{l}0.38 \\
(1.04) \\
\end{array}$ & $\begin{array}{l}0.44 \\
(1.22) \\
\end{array}$ & $\begin{array}{l}0.57 \\
(1.62) \\
\end{array}$ & $\begin{array}{l}0.68 \\
(1.99) \\
\end{array}$ & $\begin{array}{l}11.07 \\
(2.61) \\
\end{array}$ & $\begin{array}{l}13.80 \\
(3.08) \\
\end{array}$ & $\begin{array}{l}9.86 \\
(1.62) \\
\end{array}$ & $\begin{array}{l}4.48 \\
(0.88) \\
\end{array}$ & $\begin{array}{l}-1.31 \\
(-0.23) \\
\end{array}$ \\
\hline \multicolumn{13}{|c|}{ Late-Stage } \\
\hline \multirow[t]{3}{*}{60} & 6 & LWSL & & $\begin{array}{l}1.26 \\
(3.07)\end{array}$ & $\begin{array}{l}1.06 \\
(2.61)\end{array}$ & $\begin{array}{l}1.09 \\
(2.71)\end{array}$ & $\begin{array}{l}1.09 \\
(2.75)\end{array}$ & $\begin{array}{l}13.87 \\
(2.10)\end{array}$ & $\begin{array}{l}13.20 \\
(2.91)\end{array}$ & $\begin{array}{l}17.36 \\
(3.54)\end{array}$ & $\begin{array}{l}24.65 \\
(3.88)\end{array}$ & $\begin{array}{l}24.96 \\
(5.08)\end{array}$ \\
\hline & & LLSW & & $\begin{array}{l}2.21 \\
(5.37)\end{array}$ & $\begin{array}{l}2.21 \\
(5.46)\end{array}$ & $\begin{array}{l}2.29 \\
(5.35)\end{array}$ & $\begin{array}{l}2.18 \\
(5.04)\end{array}$ & $\begin{array}{l}29.96 \\
(4.32)\end{array}$ & $\begin{array}{l}23.75 \\
(3.17)\end{array}$ & $\begin{array}{l}28.17 \\
(3.46)\end{array}$ & $\begin{array}{l}25.43 \\
(2.68)\end{array}$ & $\begin{array}{l}26.47 \\
(2.90)\end{array}$ \\
\hline & & LLSW-LWSL & & $\begin{array}{l}0.95 \\
(2.19) \\
\end{array}$ & $\begin{array}{l}1.15 \\
(2.76) \\
\end{array}$ & $\begin{array}{l}1.20 \\
(2.99) \\
\end{array}$ & $\begin{array}{l}1.09 \\
(2.82) \\
\end{array}$ & $\begin{array}{l}16.09 \\
(3.52)\end{array}$ & $\begin{array}{l}10.55 \\
(1.98) \\
\end{array}$ & $\begin{array}{l}10.81 \\
(1.48)\end{array}$ & $\begin{array}{l}0.78 \\
(0.14)\end{array}$ & $\begin{array}{l}1.52 \\
(0.24)\end{array}$ \\
\hline \multicolumn{13}{|c|}{ Panel B: Subperiod 2 (January 1990 to January 2011) } \\
\hline \multicolumn{13}{|c|}{ Pure Contrarian } \\
\hline \multirow[t]{3}{*}{60} & & LW & 159.4 & $\begin{array}{l}0.71 \\
(1.47)\end{array}$ & $\begin{array}{l}0.72 \\
(1.47)\end{array}$ & $\begin{array}{l}0.77 \\
(1.53)\end{array}$ & $\begin{array}{l}0.74 \\
(1.45)\end{array}$ & $\begin{array}{l}12.64 \\
(2.21)\end{array}$ & $\begin{array}{l}10.03 \\
(1.78)\end{array}$ & $\begin{array}{l}9.42 \\
(1.55)\end{array}$ & $\begin{array}{l}10.40 \\
(1.57)\end{array}$ & $\begin{array}{l}8.67 \\
(1.32)\end{array}$ \\
\hline & & LL & 11.0 & $\begin{array}{l}0.88 \\
(2.32)\end{array}$ & $\begin{array}{l}0.79 \\
(2.08)\end{array}$ & $\begin{array}{l}0.82 \\
(2.13)\end{array}$ & $\begin{array}{l}0.76 \\
(1.97)\end{array}$ & $\begin{array}{l}10.05 \\
(2.24)\end{array}$ & $\begin{array}{l}10.11 \\
(2.10)\end{array}$ & $\begin{array}{l}9.74 \\
(1.78)\end{array}$ & $\begin{array}{l}10.27 \\
(1.77)\end{array}$ & $\begin{array}{l}10.41 \\
(1.55)\end{array}$ \\
\hline & & LL-LW & & $\begin{array}{l}0.16 \\
(0.59) \\
\end{array}$ & $\begin{array}{l}0.07 \\
(0.28) \\
\end{array}$ & $\begin{array}{l}0.05 \\
(0.19) \\
\end{array}$ & $\begin{array}{l}0.02 \\
(0.07)\end{array}$ & $\begin{array}{l}-2.59 \\
(-0.89) \\
\end{array}$ & $\begin{array}{l}0.08 \\
(0.04) \\
\end{array}$ & $\begin{array}{l}0.31 \\
(0.14) \\
\end{array}$ & $\begin{array}{l}-0.13 \\
(-0.05) \\
\end{array}$ & $\begin{array}{l}1.74 \\
(0.95) \\
\end{array}$ \\
\hline \multicolumn{13}{|c|}{ Late-Stage } \\
\hline \multirow[t]{3}{*}{60} & 6 & LWSL & & $\begin{array}{l}0.91 \\
(2.00)\end{array}$ & $\begin{array}{l}0.76 \\
(1.64)\end{array}$ & $\begin{array}{l}0.80 \\
(1.69)\end{array}$ & $\begin{array}{l}0.78 \\
(1.63)\end{array}$ & $\begin{array}{l}10.90 \\
(1.99)\end{array}$ & $\begin{array}{l}10.35 \\
(1.81)\end{array}$ & $\begin{array}{l}7.16 \\
(1.120\end{array}$ & $\begin{array}{l}13.20 \\
(1.86)\end{array}$ & $\begin{array}{l}9.17 \\
(1.40)\end{array}$ \\
\hline & & LLSW & & $\begin{array}{l}0.88 \\
(2.17)\end{array}$ & $\begin{array}{l}0.83 \\
(2.09)\end{array}$ & $\begin{array}{l}0.83 \\
(2.10)\end{array}$ & $\begin{array}{l}0.90 \\
(2.26)\end{array}$ & $\begin{array}{l}11.70 \\
(2.48)\end{array}$ & $\begin{array}{l}10.59 \\
(1.93)\end{array}$ & $\begin{array}{l}11.34 \\
(1.91)\end{array}$ & $\begin{array}{l}10.81 \\
(1.73)\end{array}$ & $\begin{array}{l}10.09 \\
(1.47)\end{array}$ \\
\hline & & LLSW-LWSL & & $\begin{array}{l}-0.03 \\
(-0.09)\end{array}$ & $\begin{array}{l}0.07 \\
(0.24)\end{array}$ & $\begin{array}{l}0.03 \\
(0.11)\end{array}$ & $\begin{array}{l}0.12 \\
(0.42)\end{array}$ & $\begin{array}{l}0.80 \\
(0.31)\end{array}$ & $\begin{array}{l}0.24 \\
(0.09)\end{array}$ & $\begin{array}{l}4.17 \\
(1.47)\end{array}$ & $\begin{array}{l}-2.38 \\
(-0.51)\end{array}$ & $\begin{array}{l}0.92 \\
(0.47)\end{array}$ \\
\hline
\end{tabular}

This table presents the average monthly holding period returns in percentages of the short, long, and arbitrage portfolios of the pure contrarian and late-stage contrarian strategies for the period January 1970 to December 1989 (Panel A) and January 1990 to January 2011 (Panel B) for developed markets. The way these portfolios are formed is described in Table 2 (for the pure contrarian strategy) and Table 3 (for the late-stage strategy). The variable Formation Return is the portfolio's J-month average formation period return in percentages. Annual event time returns (Year 1, Year 2, Year 3, Year 4, and Year 5) are the average annual returns in percentages for the first five years following the portfolio formation date. The $t$-statistics are presented in parentheses. Holding period $t$-statistics are simple $t$-statistics, whereas the annual event time $t$-statistics are based on the Newey-West (1987) correction for autocorrelation up to lag 11. 
Table 6

Risk-Adjusted Profits for the Developed Markets in Subperiods

\begin{tabular}{|c|c|c|c|c|c|}
\hline \multicolumn{6}{|c|}{ Panel A: Subperiod 1 (January 1970 to December 1989) } \\
\hline \multicolumn{6}{|c|}{ Pure Contrarian } \\
\hline \multirow[b]{2}{*}{ Portfolio } & \multirow{2}{*}{$\begin{array}{l}\text { Raw } \\
\text { Return }\end{array}$} & \multicolumn{4}{|c|}{ Two-Factor Model } \\
\hline & & $\alpha$ & $\beta$ & $\boldsymbol{v}$ & Adj $R^{2}$ \\
\hline LW & 1.30 & $\begin{array}{l}-0.210 \\
(-0.819)\end{array}$ & $\begin{array}{l}1.010 \\
(12.870)\end{array}$ & $\begin{array}{l}0.286 \\
(1.629)\end{array}$ & $58.4 \%$ \\
\hline LL & 1.73 & $\begin{array}{l}0.553 \\
(1.620)\end{array}$ & $\begin{array}{l}0.730 \\
(5.408)\end{array}$ & $\begin{array}{l}0.167 \\
(0.928)\end{array}$ & $36.6 \%$ \\
\hline LL-LW & 0.44 & $\begin{array}{l}0.763 \\
(1.853)\end{array}$ & $\begin{array}{l}-0.280 \\
(-1.729)\end{array}$ & $\begin{array}{l}-0.119 \\
(-0.481)\end{array}$ & $4.1 \%$ \\
\hline \multicolumn{6}{|l|}{ Late-Stage } \\
\hline LWSL & 1.06 & $\begin{array}{l}-0.408 \\
(-1.426)\end{array}$ & $\begin{array}{l}1.019 \\
(10.370)\end{array}$ & $\begin{array}{l}0.246 \\
(1.379)\end{array}$ & $52.6 \%$ \\
\hline LLSW & 2.21 & $\begin{array}{l}0.876 \\
(2.051)\end{array}$ & $\begin{array}{l}0.797 \\
(4.591)\end{array}$ & $\begin{array}{l}0.313 \\
(1.358)\end{array}$ & $31.6 \%$ \\
\hline LLSW-LWSL & 1.15 & $\begin{array}{l}1.284 \\
(2.537) \\
\end{array}$ & $\begin{array}{l}-0.222 \\
(-1.083) \\
\end{array}$ & $\begin{array}{l}0.067 \\
(0.226) \\
\end{array}$ & $1.7 \%$ \\
\hline \multicolumn{6}{|c|}{ Panel B: Subperiod 2 (January 1990 to January 2011) } \\
\hline \multicolumn{6}{|c|}{ Pure Contrarian } \\
\hline \multirow[b]{2}{*}{ Portfolio } & \multirow{2}{*}{$\begin{array}{l}\text { Raw } \\
\text { Return }\end{array}$} & \multicolumn{4}{|c|}{ Two-Factor Model } \\
\hline & & $\alpha$ & $\beta$ & $\boldsymbol{v}$ & Adj $R^{2}$ \\
\hline LW & 0.72 & $\begin{array}{l}0.051 \\
(0.259)\end{array}$ & $\begin{array}{l}1.271 \\
(22.090)\end{array}$ & $\begin{array}{l}-0.049 \\
(-0.566)\end{array}$ & $85.3 \%$ \\
\hline LL & 0.79 & $\begin{array}{l}0.207 \\
(1.205)\end{array}$ & $\begin{array}{l}0.955 \\
(23.564)\end{array}$ & $\begin{array}{l}0.181 \\
(1.645)\end{array}$ & $79.3 \%$ \\
\hline LL-LW & 0.07 & $\begin{array}{l}0.157 \\
(0.652) \\
\end{array}$ & $\begin{array}{l}-0.316 \\
(-4.701) \\
\end{array}$ & $\begin{array}{l}0.230 \\
(1.580)\end{array}$ & $20.2 \%$ \\
\hline \multicolumn{6}{|l|}{ Late-Stage } \\
\hline LWSL & 0.76 & $\begin{array}{l}0.054 \\
(0.256)\end{array}$ & $\begin{array}{l}1.233 \\
(18.407)\end{array}$ & $\begin{array}{l}-0.081 \\
(-0.824)\end{array}$ & $81.3 \%$ \\
\hline LLSW & 0.83 & $\begin{array}{l}0.164 \\
(0.794)\end{array}$ & $\begin{array}{l}1.006 \\
(23.711)\end{array}$ & $\begin{array}{l}0.287 \\
(1.946)\end{array}$ & $72.9 \%$ \\
\hline LLSW-LWSL & 0.07 & $\begin{array}{l}0.109 \\
(0.384)\end{array}$ & $\begin{array}{l}-0.227 \\
(-2.702)\end{array}$ & $\begin{array}{l}-0.368 \\
(1.943)\end{array}$ & $11.0 \%$ \\
\hline
\end{tabular}

This table presents the two- and three-factor regression results for the monthly returns of the pure contrarian portfolios $(J=60, K=6)$ and late-stage contrarian portfolios $(J / J 2=60 / 6, K=6)$ for the periods January 1970 to December 1989 (Panel A) and January 1990 to January 2011 (Panel B) for developed markets. The way these portfolios are formed are described in Tables 2 and 3 . The two-factor regression is as follows:

$$
R_{p t}-R_{f t}=\alpha_{p}+\beta_{p}\left(R_{w t}-R_{f t}\right)+v_{p} V M G_{t}+\varepsilon_{p t}
$$

where $R_{w t}-R_{f t}$ is the excess return on the MSCI World Market portfolio and $V M G_{t}$ is the value growth factor represented by the return on the MSCI World Value Index minus the return on the MSCl World Growth Index. Raw Return is the unadjusted monthly percent return for the respective portfolio. The $t$-statistics presented in parentheses are corrected for heteroskedasticity using White's (1980) test. 
Table 7

Reversal in the Average Developed Markets Index, DEV

\begin{tabular}{|c|c|c|c|c|c|c|c|c|c|c|}
\hline \multicolumn{11}{|c|}{ Panel A: Subperiod 1 (January 1970 to December 1989) } \\
\hline \multirow{2}{*}{$\begin{array}{l}\text { Past } \\
\text { Return }\end{array}$} & \multicolumn{5}{|c|}{ Annual Returns } & \multicolumn{5}{|c|}{ Sharpe Ratios } \\
\hline & Year 1 & Year 2 & Year 3 & Year 4 & Year 5 & Year 1 & Year 2 & Year 3 & Year 4 & Year 5 \\
\hline LO & 28.83 & 28.88 & 14.77 & 8.53 & 17.10 & 1.22 & 1.03 & 0.25 & -0.10 & 0.39 \\
\hline $\mathrm{HI}$ & 19.56 & 13.77 & 11.91 & 8.10 & 11.47 & 0.75 & 0.44 & 0.39 & 0.23 & 0.59 \\
\hline LO-HI & $\begin{array}{r}9.27 \\
(0.45)\end{array}$ & $\begin{array}{l}15.11 \\
(0.22)\end{array}$ & $\begin{array}{r}2.86 \\
(0.81)\end{array}$ & $\begin{array}{r}0.43 \\
(0.97)\end{array}$ & $\begin{array}{r}5.64 \\
(0.65)\end{array}$ & & & & & \\
\hline $\mathrm{S}_{\mathrm{LO}}-\mathrm{S}_{\mathrm{HI}}$ & & & & & & $\begin{array}{r}0.47 \\
(0.57)\end{array}$ & $\begin{array}{r}0.59 \\
(0.47)\end{array}$ & $\begin{array}{r}-0.14 \\
(0.86)\end{array}$ & $\begin{array}{r}-0.33 \\
(0.69)\end{array}$ & $\begin{array}{r}-0.20 \\
(0.81)\end{array}$ \\
\hline
\end{tabular}

Panel B: Subperiod 2 (January 1990 to January 2011)

\begin{tabular}{|c|c|c|c|c|c|c|c|c|c|c|}
\hline \multirow{2}{*}{$\begin{array}{l}\text { Past } \\
\text { Return }\end{array}$} & \multicolumn{5}{|c|}{ Annual Returns } & \multicolumn{5}{|c|}{ Sharpe Ratios } \\
\hline & Year 1 & Year 2 & Year 3 & Year 4 & Year 5 & Year 1 & Year 2 & Year 3 & Year 4 & Year 5 \\
\hline LO & 25.87 & 29.02 & 27.00 & 15.33 & 2.25 & 1.06 & 2.35 & 4.12 & 0.52 & -0.03 \\
\hline $\mathrm{HI}$ & -6.08 & 0.90 & 7.76 & 5.35 & 5.40 & -0.41 & -0.05 & 0.23 & 0.12 & 0.19 \\
\hline LO-HI & $\begin{array}{l}31.94 \\
(0.01)\end{array}$ & $\begin{array}{l}28.12 \\
(0.02)\end{array}$ & $\begin{array}{l}19.23 \\
(0.14)\end{array}$ & $\begin{array}{r}9.98 \\
(0.45)\end{array}$ & $\begin{array}{r}-3.16 \\
(0.83)\end{array}$ & & & & & \\
\hline $\mathrm{S}_{\mathrm{LO}}-\mathrm{S}_{\mathrm{HI}}$ & & & & & & $\begin{array}{r}1.47 \\
(0.07)\end{array}$ & $\begin{array}{r}2.39 \\
(0.01)\end{array}$ & $\begin{array}{r}3.89 \\
(0.00)\end{array}$ & $\begin{array}{r}0.40 \\
(0.66)\end{array}$ & $\begin{array}{r}-0.22 \\
(0.84)\end{array}$ \\
\hline
\end{tabular}

This table provides information on reversal in the equal-weighted average (denoted DEV) of $18 \mathrm{MSCl}$ developed market indices for two subperiods: January 1970 to December 1989 and January 1990 to January 2011. The past five-year return of the DEV portfolio is calculated each month. These rolling five-year returns are ranked separately for each subperiod. Past five-year returns in a subperiod are categorized as low returns (LO) if they rank in the smallest $25 \%$ of five-year returns for that subperiod. Similarly, past five-year returns in a subperiod are categorized as high returns $(\mathrm{HI})$ if they rank in the largest $25 \%$ of five-year returns for that subperiod. Annual Return for a particular subperiod and classification is the average annual return in percentages for the sth year following the end of the five-year ranking periods $(s=1,2,3,4,5)$. Similarly, the Sharpe Ratio for a particular subperiod and classification is the Sharpe ratio of the annual returns for the sth year following the end of the fiveyear ranking periods. The spread LO-HI is the difference between the $\mathrm{LO}$ and $\mathrm{HI}$ annual returns, while $\mathrm{S}_{\mathrm{LO}}-\mathrm{S}_{\mathrm{HI}}$ is the spread between LO and HI Sharpe ratios. Spread randomization $p$-values are presented in parentheses. 


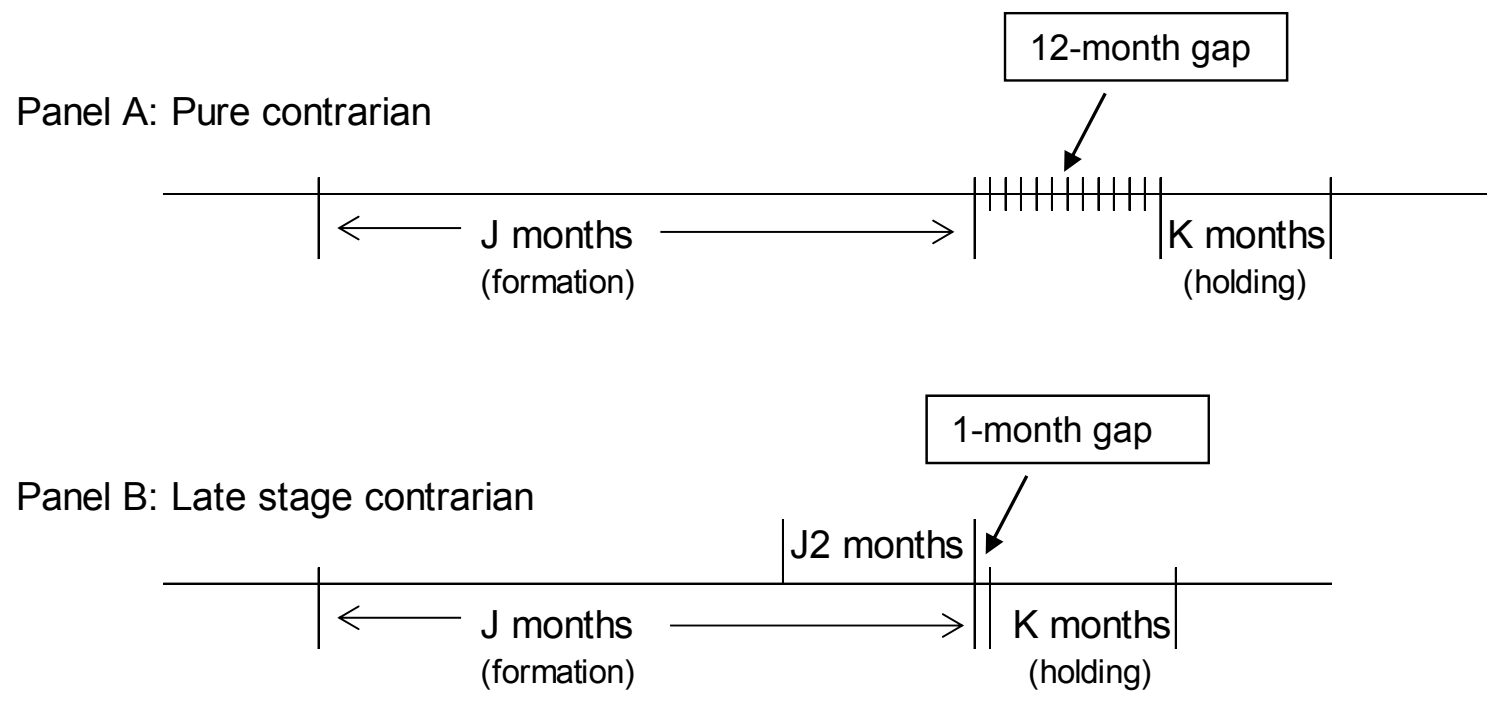

\section{Figure 1 Depiction of Formation and Holding Periods}

This graph depicts the relation between the $J$-month formation period and the $K$-month holding period for each of the strategies, with the pure contrarian strategy in Panel A and the late-stage strategy in Panel B. The second sort in the late-stage strategy is based on the returns in the most recent $J 2$ months within the $J$-month formation period. 


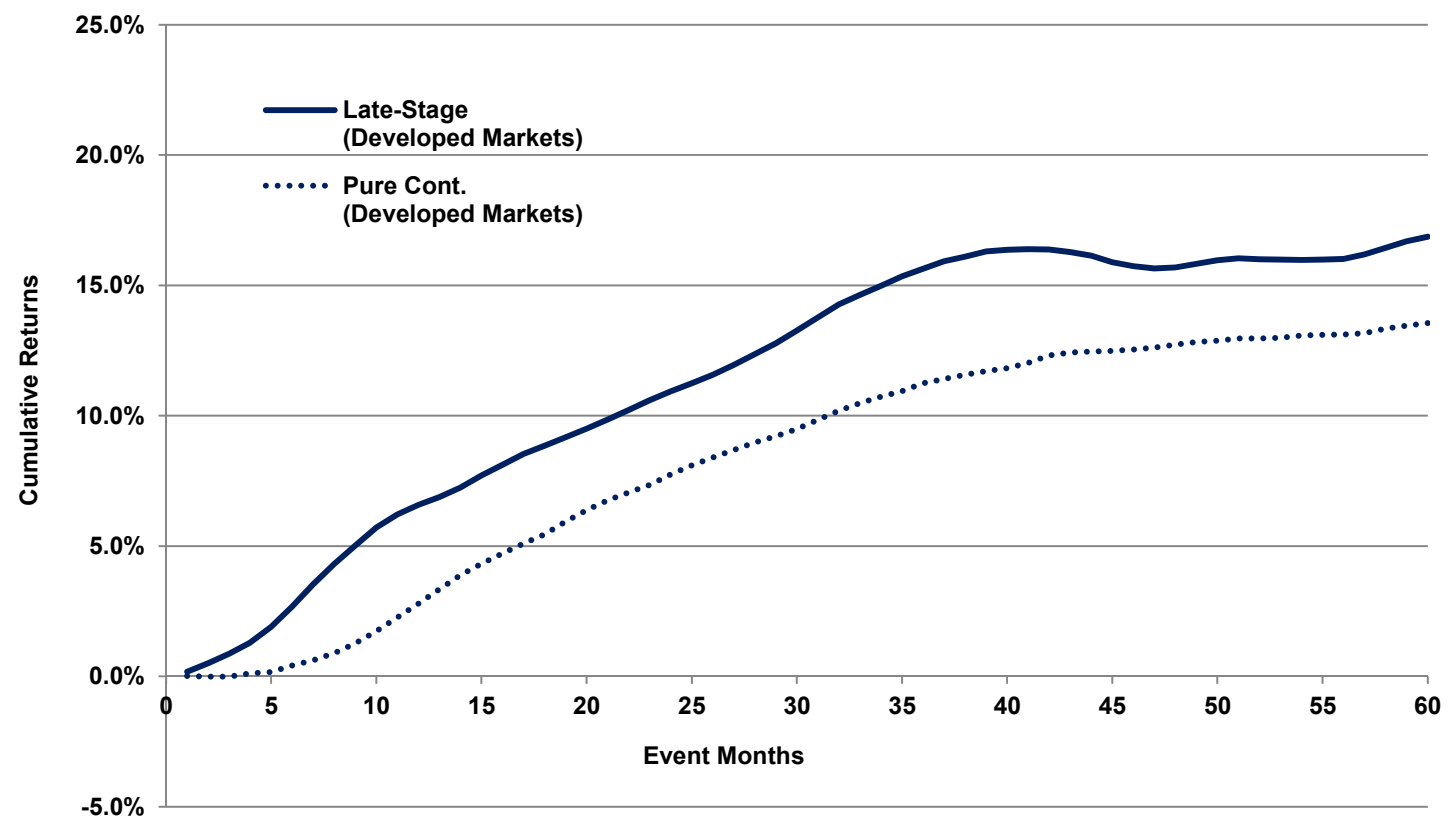

Figure 2 Cumulative Returns of Strategies: Developed Markets

The graph presents the cumulative returns of the late-stage portfolio LLSW-LWSL (with $J / J 2=60 / 6$ ) and the cumulative returns of the pure contrarian portfolio LL-LW (with $J=60$ ) using non-overlapping portfolios $(K=1)$ for the developed markets case for the 60 months following the end of the formation period. 


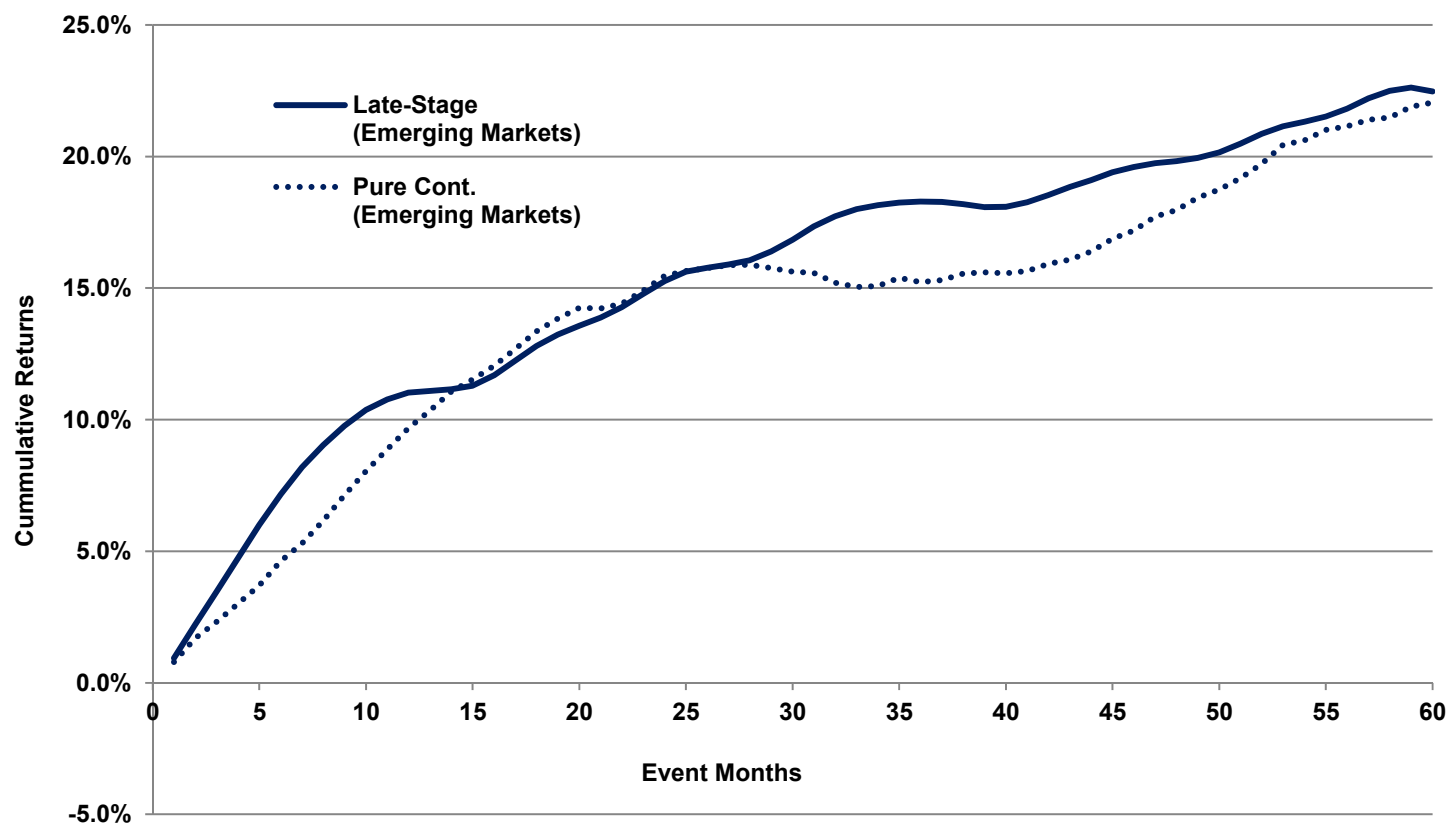

Figure 3 Cumulative Returns of Strategies: Emerging Markets

The graph presents the cumulative returns of the late-stage portfolio LLSW-LWSL (with $J / J 2=60 / 6$ ) and the cumulative returns of the pure contrarian portfolio LL-LW (with $J=60$ ) using non-overlapping portfolios $(K=1)$ for the emerging markets case for the 60 months following the end of the formation period. 